Original article (short paper)

\title{
Association between osteoporosis, health-related productivity loss and use of hospital services in outpatients of the Brazilian National Health System
}

\author{
Ana Paula Rodrigues Rocha \\ Bruna Camilo Turi-Lynch \\ Universidade Estadual Paulista “Júlio de Mesquita Filho”, Presidente Prudente, SP, Brazil \\ Luana Carolina de Morais \\ Monique Yndawe Castanho Araujo \\ Universidade Estadual Paulista "Júlio de Mesquita Filho", Rio Claro, SP, Brazil \\ Caroline Paula Cristina Palomo \\ Romulo Araújo Fernandes \\ Jamile Sanches Codogno \\ Universidade Estadual Paulista “Júlio de Mesquita Filho", Presidente Prudente, SP, Brazil
}

\begin{abstract}
Aims: To analyze factors associated with osteoporosis among outpatients of the Brazilian National Health System and to identify their association with hospital and labor economic outcomes. Methods: Cross-sectional study carried out in the city of Presidente Prudente / SP. The sample consisted of 542 adults of both sexes and aged $\geq$ 50 years old. The occurrence of osteoporosis, health-related productivity loss, use of hospital services and level of physical activity were assessed using questionnaires. Statistical analysis was composed of chi-square test, binary logistic regression and Mann-Whitney test. The significance level adopted was p-value $<0.05$. Results: The prevalence of osteoporosis was $14.4 \%(95 \% \mathrm{CI}: 11.4 \%-17.3 \%)$ and it was associated with female sex $(\mathrm{p}=0.001)$, lower economic status $(p$-value $=0.036)$ and obesity $(p$-value $=0.003)$. Participants with osteoporosis showed a higher incidence of surgery in the last 12 months $(\mathrm{OR}=2.13$ [1.04 to 4.35]), productivity loss $(\mathrm{OR}=1.91$ [1.13 to 3.42]) and disability retirement $(\mathrm{OR}=2.03$ [1.20 to 3.43]). Over the past 12 months, the sum of direct and indirect economic loss was $\mathrm{R} \$$ $1,382,630.00$. Conclusion: The female sex, lower economic status and obesity were associated with a higher occurrence of osteoporosis, and consequent higher use of hospital services and significant economic losses.
\end{abstract}

Keywords: osteoporosis, Healthcare cost, Health care System

\section{Introduction}

Osteoporosis is defined as a chronic disease, and it is characterized by decreased bone mass and possible associations with fractures ${ }^{1}$. In Brazil, a prevalence study performed with more than 50,000 adults of both sexes identified that $4.4 \%$ of the participants reported the medical diagnosis of the disease, with higher levels among females ${ }^{2}$.

The disease is a public health concern due to its significant impact on health care expenditure ${ }^{3,4}$. In Australia, cost report about osteoporosis published in 2012 showed that direct and indirect costs with the disease were above 2 billion dollars. Direct costs represented $94 \%$ of total expenses, and the loss was even bigger in the presence of fractures $(\$ 1,759,572,690$ with fractures versus $\$ 829,645,097$ without fracture $)^{3}$.

Regarding this issue, studies about the economic burden of the disease are important to guide actions in health, mainly preventing fractures ${ }^{5,6}$. Economic assessment helps to clarify the costs of treatments and can be used with different approaches, especially in the health care area, where expenditures related to the disease can be analyzed from the payer's perspective and the social perspective ${ }^{7}$.

Recently, productivity loss has been highlighted in studies analyzing economic assessment and costs of diseases ${ }^{8-11}$. Regarding this issue, studies involving economic evaluation in chronic diseases, such as osteoporosis, may guide future actions for promotion and management of health.

Therefore, the objectives of the study were (i) to analyze factors associated with osteoporosis among outpatients of the Brazilian National Health System, and (ii) to identify their association with hospital and labor economic outcomes.

\section{Methods}

Sample

This study had a cross-sectional design and was carried out with outpatients of two Basic Healthcare Units (BHU) located in the city of Presidente Prudente, the western region of São 
Paulo State. Before implementation, the study was approved by the Ethics Committee Group from São Paulo State University, Presidente Prudente Campus (Process number: 241291/2013).

The sample size calculation considered the prevalence of osteoporosis of $4.4 \% 2$, an error of $2 \%, Z=1.96$ and population of the city of 200,000 inhabitants, estimating a minimum of 403 participants. At the end of data collection, the sample consisted of 542 adults of both sexes.

The two BHU were indicated by the Municipal Health Department and were located in densely populated areas. Properly trained undergraduate and masters students performed data collection during mornings and afternoons. During 60 days, all participants attending the BHU were invited to participate in the study, as long as they met the inclusion criteria. Firstly, all subjects needed to be aged $\geq 50$ years old, because this age has been correlated with development of chronic diseases in the Brazilian population ${ }^{12,13}$ and is a cutoff point relating to significantly increased health care costs among adults ${ }^{14}$. Secondly, all subjects need to have attended at least one medical consultation during the last six months: this was used as an indicator of current residence in Presidente Prudente and usage of the healthcare system. Individuals who accepted to participate in the evaluations signed the consent form.

\section{Diagnosis of osteoporosis}

The occurrence of osteoporosis was identified through a face-toface interview using a morbidity questionnaire ${ }^{15}$ and confirmation was based on physician diagnosis identified through medical records of the participants. The participants were divided into two groups: the presence of osteoporosis and absence of osteoporosis.

\section{Health-related productivity loss and use of hospital services}

During the interviews, participants were asked about labor activities, such as income, absenteeism in the last year (cause and number of events), and disability retirement (cause, period and amount of money received). Costs of productivity loss were calculated as a product of the daily wage (calculated by dividing average monthly wage by number of working days), and working days missed (due to illness) during the last 12 months.

It was considered as: (i) direct productivity loss: economic losses related to working days missed due to illness; (ii) indirect productivity loss: economic losses related to early retirement due to illness (before 60 or 65 years old for women and men, respectively); and (iii) total loss: the sum of direct and indirect economic losses. For statistical analysis, the patients were grouped into two groups, according to the percentile of monetary values (in Real [R $\$]$ ): $<$ P75 (patients with the lowest values of productivity losses) and $>$ P75 (patients with the highest values of productivity loss).

Additionally, we collected information about the use of hospital services in the 12 months before the interview through medical records (surgeries and hospitalizations).

\section{Habitual physical activity level}

The level of physical activity was estimated using the questionnaire developed by Baecke, Burema, Frijters ${ }^{16}$ (composed of 16 questions scored on a 5-points Likert scale ranging from never to always/very often), which considers three domains of physical activity: occupational (08 questions taking into account intensity and behaviors during work: sitting, standing, walking, lifting heavy loads, sweating and feeling tired), sport participation (01 question stratified into three questions taking into account intensity, weekly time [in hours] and previous time of practice [in months]) and leisure-time (07 questions taking into account behaviors during leisure-time like play sports, watching television, walking and cycling). The physical activity level was calculated by specific equations and was expressed as scores for each domain (higher score denotes higher physical activity) and the sum of all domains constitutes the overall physical activity. The sample was then divided into quartiles and participants were classified into four groups: Physically inactive $(<\mathrm{P} 25)$, Moderately Active $(<$ P25 and $>$ P75) and Sufficiently Active ( $>$ P75).

\section{Potential confounders}

Chronological age and gender were obtained during face-to-face interview. Economic status was assessed by a specific and previously validated Brazilian questionnaire 14 , which estimates family income according to possession of items and education level of the head of the family into eight categories: A1, A2, B1, B2, C1, $\mathrm{C} 2, \mathrm{D}$ and $\mathrm{E}$, with " $\mathrm{A}$ " being the highest and " $\mathrm{E}$ " the lowest. Body mass index (BMI) was calculated using measurements of weight and height and obtained by dividing weight by squared height $(\mathrm{kg} / \mathrm{m} 2)$. Obesity was defined as BMI $\geq 30 \mathrm{~kg} / \mathrm{m} 2^{17}$.

\section{Statistical analysis}

Descriptive statistics were expressed as mean, median, interquartile range (IR), 95\% confidence interval $(95 \% \mathrm{CI})$ and percentage. Categorical variables were expressed as rates and compared by the chi-square test (Yates's correction was applied in $2 \times 2$ tables). Significant associations detected by chi-square test were further analyzed by the binary logistic regression, which generated values of odds ratio (OR) and 95\% CI. Comparisons between groups with and without osteoporosis were performed by the Mann-Whitney U test due to non-normal distributed data. All statistical analyses were performed by the software BioEstat (release 5.0) and statistical significance (p-value) was set at 0.05 .

\section{Results}

A total of 542 patients, $70.3 \%(n=381)$ females and $29.7 \%$ $(\mathrm{n}=161)$ males, and the mean age was $61.9 \pm 9.2$ years. Among the analyzed group, $34.7 \%$ of the patients were older than 65 years old and 78 participants were diagnosed with osteoporosis, which corresponds to $14.4 \%$ (95\% CI: $11.4 \%$ - 17.3\%). 
The occurrence of osteoporosis was associated with female sex $(p$-value $=0.001)$, lower economic status $(p$-value $=0.036)$ and obesity $(\mathrm{p}$-value $=0.003)($ Table 1$)$.

Table 2 shows the association of osteoporosis with healthrelated productivity loss and use of hospital services. Associations were found between osteoporosis and higher occurrence of surgery in the last 12 months ( $p$-value $=0.020$ ), higher chances of being retired due to disability $(p$-value $=0.001)$ and being located in the group with higher productivity loss ( $p$-value = 0.007). The results remained significant even after adjustment by age, sex, economic status, physical activity level and BMI. Patients with osteoporosis were 2.13 more likely to need surgery, 1.91 more likely to be in the highest percentile of productivity loss and 2.03 more likely to retire due to health issues when compared to patients without the disease.

Table 3 shows health-related productivity loss in Brazilian currency (Reais - R\$) according to the diagnosis of osteoporosis. The results are presented with median, interquartile range, mean and $95 \% \mathrm{CI}$ for better visualization. The indirect losses were higher in patients with osteoporosis (Presence of osteoporosis: R\$ 3,190.77 versus Absence of osteoporosis: $\mathrm{R} \$ 2,329.76$, p-value $=0.017$ ), as well as the total loss (Presence of osteoporosis: R \$ 3,251.09 versus Absence of osteoporosis: $\mathrm{R} \$ 2,433.29$, p-value $=0.010)$. Over the last 12 months, direct economic losses computed R\$ 52,742.00 and indirect $\mathrm{R} \$ 1,329,888.00$.

Table 1. Occurrence of osteoporosis according to descriptive characteristics of the sample ( $\mathrm{n}=78$; Presidente Prudente, 2013).

Outcome (Osteoporosis)

Variables

Sex

Male

Female

Age

$<65$ years

$>65$ years

Physical activity level

Physically active

Moderately active

Physically inactive

Economic status

$\mathrm{B} 1$ and $\mathrm{B} 2$

$\mathrm{C} 1$ and $\mathrm{C} 2$

$\mathrm{D}$ and $\mathrm{E}$

Body mass index

Normal

Overweight

Obesity
$09(5.6)$

$69(18.1)$

$31(16.5)$

$47(13.3)$

$15(11.1)$

$42(15.2)$

$21(16)$

$16(10.8)$

$44(14.2)$

18 (21.2)

42 (19.3) n (\%)

Chi-square ( $p$-value) 
Table 2. Association between osteoporosis, use of hospital services and productivity loss in outpatients of the Brazilian National Health System ( $\mathrm{n}=78$; Presidente Prudente, 2013).

\begin{tabular}{|c|c|c|c|}
\hline \multirow{2}{*}{ Variables } & \multicolumn{2}{|c|}{ Chi-square } & \multirow{2}{*}{$\frac{\text { Logistic Regression }}{\text { OR (CI95\%)* }}$} \\
\hline & n (\%) & $p$-value & \\
\hline Hospitalization $_{12 \text { months }}$ & & 0.527 & \\
\hline Osteoporosis (No) & $67(14.4)$ & & --- \\
\hline Osteoporosis (Yes) & $14(17.9)$ & & --- \\
\hline Surgery 12 months & & 0.020 & \\
\hline Osteoporosis (No) & $36(7.8)$ & & 1.00 \\
\hline \multirow[t]{2}{*}{ Osteoporosis (Yes) } & $13(16.7)$ & & $2.13(1.04$ a 4.35$)$ \\
\hline & & & H-L $(p-v a l u e=0.222)$ \\
\hline Absenteeism $_{12 \text { months }}$ & & 0.459 & \\
\hline Osteoporosis (No) & $33(7.1)$ & & --- \\
\hline Osteoporosis (Yes) & $08(10.3)$ & & --- \\
\hline Productivity Loss $(\geq \mathrm{P} 75)$ & & 0.007 & \\
\hline Osteoporosis (No) & $103(22.2)$ & & 1.00 \\
\hline \multirow[t]{2}{*}{ Osteoporosis (Yes) } & $29(37.2)$ & & 1.91 (1.13 a 3.42) \\
\hline & & & H-L (p-value $=0.258)$ \\
\hline Disability Retirement & & 0.001 & \\
\hline Osteoporosis (No) & $107(23.1)$ & & 1.00 \\
\hline Osteoporosis (Yes) & $32(41.1)$ & & $2.03(1.20$ a 3.43$)$ \\
\hline & & & H-L $(p-$ value $=0.310)$ \\
\hline
\end{tabular}

Notes: *= adjusted by age, sex, economic status, physical activity and body mass index; H-L= Hosmer-Lemeshow test; P75= percentile 75.

Table 3. Health-related productivity loss according to osteoporosis diagnosis ( $\mathrm{n}=78$; Presidente Prudente, 2013).

\begin{tabular}{|c|c|c|c|}
\hline \multirow{3}{*}{ Productivity Loss (R\$) } & \multicolumn{2}{|c|}{ Osteoporosis Diagnosis } & \multirow{3}{*}{$p$-value* } \\
\hline & Presence $(n=78)$ & Absence $(n=464)$ & \\
\hline & Median (IR) Mean $[95 \% \mathrm{CI}]$ & Median (IR) Mean [95\%CI] & \\
\hline Direct & $0.00(0) 60.32[1.00$ to 147.21$]$ & $0.00(0) 103.53[32.3$ to 174.74$]$ & 0.509 \\
\hline Indirect & 0.00 (8136) 3190.77 [2178.27 to 4203.27 ] & $0.00(0) 2329.76$ [1856.69 to 2802.83$]$ & 0.017 \\
\hline Total & $0.00(8137) 3251.09$ [2244.30 to 4257.87$]$ & 0.00 (77) 2433.29 [1951.95 to 2914.62$]$ & 0.010 \\
\hline
\end{tabular}

Notes: *= Mann-Whitney test; $\mathrm{IR}=$ Interquartile range; $95 \% \mathrm{CI}=95 \%$ Confidence Interval. 


\section{Discussion}

The present study aimed to investigate the association between osteoporosis and health-related productivity losses and use of hospital services in outpatients of the Brazilian National Health System and identified that people with osteoporosis had higher direct and indirect costs to the federal government, were more likely to retire due to disability and have surgeries.

Regarding the association between the occurrence of osteoporosis and female sex, it can be confirmed by other studies ${ }^{18-20}$. According to Holroyd, Cooper, Dennison ${ }^{21}$, the risk of fracture due to osteoporosis is $50 \%$ among women and $20 \%$ among men over 50 years of age. Women are more likely to develop osteoporosis because they get lower bone mass during puberty and lose more bone mass during the aging process ${ }^{22}$, as well as they tend to be less active throughout life $\mathrm{e}^{23}$.

In the present study, the occurrence of osteoporosis was also associated with lower economic status. Thorpe, Kasper, Szanton, Frick, Fried, Simonsick ${ }^{24}$ suggested that lower income had a strong association with functional decline and occurrence of diseases, showing that $81.4 \%$ of the participants with lowincome presented some chronic disease, such as osteoporosis. Our study emphasizes that lower income can cause harmful occupational and environmental exposure, contributing to poorer health status and thus functionally in this population ${ }^{25}$. The income-related inequalities can affect physical activity, access to resources and opportunities of social engagement ${ }^{23}$. Eventually, fewer resources are available to compensate these limitations, causing a cycle of health-related poverty ${ }^{24}$.

We also observed that increased BMI was associated with osteoporosis. Although overweight causes greater mechanical stress on the skeleton, which may boost bone mass gain ${ }^{26}$, adipose tissue also releases inflammatory agents that impair bone formation, such as interleukin-6. These pro-inflammatory agents stimulate the activity of osteoclasts and bone resorption through the modification of proteins. Moreover, excess secretion of leptin by adipocyte may directly or indirectly affect bone formation and resorption through inflammation regulated by cytokines ${ }^{27}$.

Another finding of our study regarded the use of hospital services and showed that patients with osteoporosis were 2.13 more likely of going into surgery than a patient without the disease. It is known that osteoporosis is a significant risk factor for several fractures, which can lead to surgical procedures ${ }^{28}$. Treatment of osteoporosis involves a high economic burden, making the disease a public health problem. A study conducted by Rousculp, Long, Wang, Schoenfeld, Meadows ${ }^{29}$ aimed to investigate annual direct medical costs of fractures related to osteoporosis and analyzed hospitalization expenditures, nursing home visits, home health visits, emergency services, outpatient services, and medication prescriptions. They concluded that medical treatment of patients with osteoporosis plus fractures is substantially superior to in patients with the same comorbidity without fractures and, corroborating our findings, suggests that treating osteoporosis as prevention of fractures could reduce health costs.

Additionally, several other medical disorders are associated with osteoporosis and the increased risk of fractures, so recently studies have considered osteoporosis as a secondary disease $\mathrm{e}^{30,31}$. Among these medical disorders are genetic, endocrine, gastrointestinal, hematologic and kidney diseases, congestive heart failure, nutritional deficiency, alcoholism and prolonged use of drugs $^{1,30,31}$. This context helps to explain the results obtained, since several therapeutic approaches, including surgeries, may be necessary for the treatment of osteoporosis and the associated diseases mentioned above ${ }^{32}$.

The indirect health costs, represented by health-related productivity loss in this study, showed interesting results (productivity loss and disability retirement), representing important social and economic impact within the scope of public health policies. A study conducted in Canada analyzing the economic burden of osteoporosis in men concluded that $\$ 28$ million are spent with productivity loss in individuals who have suffered fractures from the disease ${ }^{33}$. In 2012, a report was published in Australia showing the estimated indirect cost of $\$ 165.2$ million with men and women who suffered fractures due to osteoporosis ${ }^{3}$. Our data also present worrying results, showing that even in a small group of 542 patients, the sum of economic losses in 12 months was significant ( $\mathrm{R} \$ 1,382,630.00)$. These values identify that osteoporosis is an economic burden for the Brazilian government.

The main limitations of this study need to be highlighted. Initially, the use of only two BHU may limit the generalization of our findings, even considering the large population group that they cover. Likewise, the absence of more accurate measurements of bone mineral density needs to be emphasized. Finally, it should be pointed out that the estimates of economic loss presented here are underestimated, given the fact that obtaining valid data on expenditures related to hospitalizations and surgical procedures is difficult.

\section{Conclusion}

In summary, the findings of the present study identify that female gender, lower economic status and obesity are associated with a higher occurrence of osteoporosis, whereas it was associated with higher use of hospital services and significant economic losses.

\section{References}

1. Conference C. Osteoporosis Prevention, Diagnosis, and Therapy. 2001;285(6).

2. Martini LA, Moura EC De, Santos LC Dos, Malta DC, Pinheiro MDM. Prevalência de diagnóstico auto-referido de osteoporose, Brasil, 2006. Rev Saude Publica. 2009;43(Supl 2):107-16.

3. Watts JJ, Abimanyi-ochom J, Sanders KM. Osteoporosis costing all Australians A new burden of disease analysis - 2012 to 2022 [Internet]. 2012. Available from: www.osteoporosis.org.au

4. Parthan A, Kruse M, Agodoa I, Silverman S, Orwoll E. Denosumab: A cost-effective alternative for older men with osteoporosis from a Swedish payer perspective. Bone. 2014;59:105-13. 
5. Yates CJ, Chauchard M, Liew D, Bucknill A, Wark JD. Bridging the Osteoporosis Treatment Gap: Performance and CostEffectiveness of a Fracture Liaison Service. J Clin Densitom [Internet]. 2015;18(2):150-6.

6. O’Malley NT, Blauth M, Suhm N, Kates SL. Hip fracture management, before and beyond surgery and medication: a synthesis of the evidence. Arch Orthop Trauma Surg. 2011;1-9.

7. Shiroiwa T, Fukuda T, Ikeda S, Shimozuma K. QALY and productivity loss: Empirical evidence for "double counting." Value Heal [Internet]. 2013;16(4):581-7. Available from: http://dx.doi. org/10.1016/j.jval.2013.02.009

8. Zhang W, Bansback N, Boonen A, Severens JL, Anis AH. Development of a composite questionnaire, the valuation of lost productivity, to value productivity losses: Application in rheumatoid arthritis. Value Heal [Internet]. 2012;15(1):46-54. Available from: http://dx.doi.org/10.1016/j.jval.2011.07.009

9. Zhang W, Bansback N, Anis AH. Measuring and valuing productivity loss due to poor health: A critical review. Soc Sci Med [Internet]. 2011;72(2):185-92. Available from: http://dx.doi. org/10.1016/j.socscimed.2010.10.026

10. Tosteson ANA, Vanness DJ. Osteoporosis [Internet]. Vol. I, The Economics of Osteoporosis. Elsevier; 2008 [cited 2015 Apr 24]. 37-45 p. Available from: http://www.sciencedirect.com/science/ article/pii/B9780123705440500057

11. Brod M, Wolden M, Christensen T, Bushnell DM. Understanding the economic burden of nonsevere nocturnal hypoglycemic events: Impact on work productivity, disease management, and resource utilization. Value Heal [Internet]. 2013;16(8):1140-9. Available from: http://dx.doi.org/10.1016/j.jval.2013.09.002

12. Kilsztajn S, Silva DF da, Camara MB da, Ferreira VS. Grau de cobertura dos planos de saúde e distribuição regional do gasto público em saúde. Saúde e Soc [Internet]. 2001 Dec [cited 2017 May 28];10(2):35-46. Available from: http://www.scielo.br/scielo.php?script=sci_arttext\&pid=S0104-12902001000200004\&ln $\mathrm{g}=\mathrm{pt} \& \mathrm{t} \operatorname{lng}=\mathrm{pt}$

13. Fernandes RA, Zanesco A. Early sport practice is related to lower prevalence of cardiovascular and metabolic outcomes in adults independently of overweight and current physical activity. Medicina (B Aires) [Internet]. 2015 [cited 2017 May 28];51(6):336-42. Available from: http://www.sciencedirect.com/science/article/ pii/S1010660X15000907

14. Meerding WJ, Bonneux L, Polder JJ, Koopmanschap MA, van der Maas PJ. Demographic and epidemiological determinants of healthcare costs in Netherlands: cost of illness study. BMJ [Internet]. 1998 Jul 11 [cited 2017 May 28];317(7151):111-5. Available from: http://www.ncbi.nlm.nih.gov/pubmed/9657785

15. Freitas Junior IFFU, Castoldi RC, Moreti DG, Pereira ML, Cardoso ML, Codogno JS, et al. Aptidão Física, História Familiar e Ocorrência de Hipertensão Arterial, Osteoporose, Doenças Metabólicas e Cardíacas entre Mulheres. Rev SOCERG [Internet]. 2009;22(3):158-64. Available from: http://sociedades.cardiol.br/ socerj/revista/2009_03/a2009_v22_n03_04romulo.pdf

16. Baecke J, Burema J, Frijters J. The Questionnaire of Baecke et al for Measurement of a Person's Habitual Physical Activity. Am J Clin Nutr [Internet]. 1982;936-42. Available from: http://geriatricphysiotherapy.yolasite.com/resources/Baecke_questionnaire_for Measurement_of_a_Person's_Habitual_Physical_Activity.pdf
17. ASSOCIAÇÃO BRASILEIRA DE EMPRESAS DE PESQUISA. Critério de Classificação Econômica [Internet]. Levantamento sócio econômico-2010-IBOPE. 2012. Available from: http://www. abep.org/Servicos/Download.aspx?id=03

18. WHO. Obesity: preventing and managing the Global Epidemic. Rep a WHO Expert Consult Obes [Internet]. 1997;1(June):3-5. Available from: http://www.who.int/nutrition/publications/obesity_executive_summary.pdf

19. Van Staa TP, Dennison EM, Leufkens HGM, Cooper C. Epidemiology of fractures in England and Wales. Bone. 2001;29(6):517-22.

20. Murray CJL, Vos T, Lozano R, Naghavi M, Flaxman AD, Michaud C, et al. Disability-adjusted life years (DALYs) for 291 diseases and injuries in 21 regions, 1990-2010: A systematic analysis for the Global Burden of Disease Study 2010. Lancet. 2012;380(9859):2197-223.

21. Holroyd C, Cooper C, Dennison E. Epidemiology of osteoporosis. Best Pract Res Clin Endocrinol Metab [Internet]. 2008 Oct [cited 2015 Apr 21];22(5):671-85. Available from: http://www.sciencedirect.com/science/article/pii/S1521690X08000766

22. Manolagas SC. From estrogen-centric to aging and oxidative stress: A revised perspective of the pathogenesis of osteoporosis. Endocr Rev. 2010;31(3):266-300.

23. Fernandes RA, Zanesco A. Early physical activity promotes lower prevalence of chronic diseases in adulthood. Hypertens Res. 2010;33(9):926-31.

24. Thorpe RJ, Kasper JD, Szanton SL, Frick KD, Fried LP, Simonsick EM. Relationship of race and poverty to lower extremity function and decline: findings from the Women's Health and Aging Study. Soc Sci Med. 2008;66(4):811-21.

25. Williams DR, Collins C. Racial residential segregation: a fundamental cause of racial disparities in health. Public Health Rep. 2001;116(5):404-16.

26. Carlos M, Lima S, Cayres SU, Agostinete RR, Ito IH. Estabilidade da prática esportiva durante a infância / adolescência e densidade mineral óssea na idade adulta Tracking of sports activity during. Rev Bras Atividade Física e Saúde. 2013;18(4):445-52.

27. Fujita Y, Watanabe K, Maki K. Serum leptin levels negatively correlate with trabecular bone mineral density in high-fat dietinduced obesity mice. J Musculoskelet Neuronal Interact. 2012;12(2):84-94.

28. Baccaro LF, Conde DM, Costa-Paiva L, Pinto-Neto AM. Clinical Interventions in Aging Dovepress The epidemiology and management of postmenopausal osteoporosis: a viewpoint from Brazil. Clin Interv Aging [Internet]. 2015;10:583-91. Available from: http://www.dovepress.com/the-epidemiology-and-management-ofpostmenopausal-osteoporosis-a-viewp-peer-reviewed-article-CIA

29. Rousculp MD, Long SR, Wang S, Schoenfeld MJ, Meadows ES. Economic burden of osteoporosis-related fractures in medicaid. Value Heal [Internet]. 2007;10(2):144-52. Available from: http:// dx.doi.org/10.1111/j.1524-4733.2006.00161.x

30. Soriano R, Herrera S, Nogués X, Diez-Perez A. Current and future treatments of secondary osteoporosis. Best Pract Res Clin Endocrinol Metab [Internet]. 2014;28(6):885-94.

31. Emkey GR, Epstein S. Secondary osteoporosis: Pathophysiology \& diagnosis. Bailliere's Best Pract Res Clin Endocrinol Metab 
[Internet]. 2014;28(6):911-35. Available from: http://dx.doi. org/10.1016/j.beem.2014.07.002

32. Singh A, Adams AL, Burchette R, Dell RM, Funahashi TT, Navarro RA. The effect of osteoporosis management on proximal humeral fracture. J shoulder Elb Surg / Am Shoulder Elb Surg . [et al] [Internet]. 2015;24(2):191-8. Available from: http://dx.doi. org/10.1016/j.jse.2014.07.005

33. Tarride JE, Guo N, Hopkins R, Leslie WD, Morin S, Adachi JD, et al. The burden of illness of osteoporosis in Canadian men. $\mathrm{J}$ Bone Miner Res. 2012;27(8):1830-8.

\section{Corresponding author}

\section{Ana Paula Rodrigues Rocha}

Universidade Estadual Paulista "Júlio de Mesquita Filho", Campus de Presidente Prudente, Fisioterapia. Roberto Simonsen, 305, Bela Vista, Presidente Prudente, SP. Email: rodrigues.anarocha@gmail.com

Manuscript received on April 13, 2017

Manuscript accepted on May 3, 2017

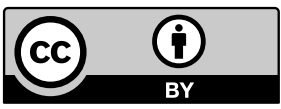

Motriz. The Journal of Physical Education. UNESP. Rio Claro, SP, Brazil - eISSN: 1980-6574 - under a license Creative Commons - Version 3.0 